\title{
Editorial
}

\section{O Diagnóstico dos transtornos mentais}

\author{
Mario Francisco Juruena ${ }^{1}$
}

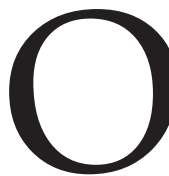

$\mathrm{s}$ transtornos mentais e os relacionados

ao uso de substâncias são os principais

contribuintes para a carga de incapaci-

tação global de todas as doenças médicas e sua gravidade está aumentando, especialmente nos países em desenvolvimento. Considerando a alta incidência das doenças mentais, se faz necessário cada vez mais o diagnóstico, acompanhamento e tratamento precoce. ${ }^{1}$

Um problema-chave do diagnóstico é o fato de que os elaborados sistemas de classificação hoje existentes baseiam-se somente em descrições subjetivas dos sintomas. Tal fenomenologia detalhada inclui a descrição de múltiplos subtipos clínicos; no entanto, não existem evidências suficientes de características biológicas que diferenciem um subtipo do outro. Além disso, reconhece-se que uma variedade de transtornos podem exibir sintomas clínicos semelhantes, e que um mesmo transtorno pode se manifestar de forma distinta em pessoas diferentes. ${ }^{2}$
Sendo assim, uma abordagem que descreva achados neurobiológicos confiáveis baseados na síndrome psicopatológica seria mais consistente do que um sistema não-etiológico de classificação como os atuais DSM e CID. Um futuro sistema de critérios diagnósticos em psiquiatria, em que a etiologia e a fisiopatologia sejam essenciais na tomada de decisões diagnósticas, colocaria a psiquiatria mais próxima de outras especialidades médicas. O potencial de um enfoque integrador para contribuir com as melhorias na saúde e bem-estar humano é mais importante do que os vieses históricos que têm sido associados à abordagem científica. ${ }^{3}$

Os ambientes sociais e físicos têm um enorme impacto em nossa fisiologia e comportamento e influenciam o processo de adaptação. É correto afirmar, ao mesmo tempo, que nossas experiências alteram nosso cérebro e pensamentos, isto é, modificando nossa mente, alteramos nossa neurobiologia. Os genes, o estresse precoce, as experiências
1.Docente, Departamento de Neurociências e Ciências do Comportamento da FMRP-USP. Prof. Visitante do Instituto de Psiquiatria, Psicologia e Neurociências do King's College London e Fellow Academy of Medical Sciences/Royal Society, UK.
CoRresPondÊNCiA:

Prof. Dr. Mario F. Juruena Saúde Mental - USP

Rua Tenente Catão Roxo, 2650 CEP: 14051-140 - Ribeirão Preto/SP e-mail: juruena@fmrp.usp.br

Recebido em 08/02/2016 Aprovado em 22/08/2016 
na vida adulta, o estilo de vida e as experiências de vida estressantes contribuem como forma pela qual o corpo se adapta a um meio ambiente mutável; e todos esses fatores ajudam a determinar o custo para o corpo e a mente. ${ }^{4}$

O modelo interativo está baseado em evidências de que, embora os genes aumentem a sensibilidade da pessoa ao estresse, também podem moldar fatores de personalidade que, na realidade, aumentam as chances de a pessoa apresentar depressão.

A vulnerabilidade biológica ou genética envolve múltiplos genes que interagem com as influências ambientais, moldam a natureza da química cerebral da pessoa e podem moldar as características da personalidade, como a instabilidade emocional. Os neurotransmissores, tais como a serotonina e a noradrenalina, ajudam a regular o humor e estão mais intimamente ligados ao sistema humano de resposta ao estresse.

A vulnerabilidade psicológica envolve comportamentos moldados por fatores como timidez e busca excessiva de reasseguramento. Os estudos recentes indicam que a resolução dos problemas protege as pessoas de eventos estressantes da vida.

Os eventos estressantes da vida, especialmente perdas pessoais, negligência e abuso físico, emocional ou sexual, aumentam a probabilidade de doença mental ao tornarem a resposta cerebral ao estresse mais hipersensível e intensa.
Os fatores cognitivos - memória, atenção, pensamentos e crenças gerais de uma pessoa a respeito do mundo e dos relacionamentos - podem causar doença mental. As relações interpessoais e exigências sociais são fatores sociais e emocionais que afetam a qualidade dos relacionamentos e estão ligados ao estresse. $\mathrm{O}$ apoio social positivo reduz este, ao passo que os relacionamentos negativos o aumentam.

Em vista da alta prevalência e incidência de transtornos psiquiátricos, modestos investimentos na assistência a pacientes psiquiátricos podem resultar em benefício biopsicossocial e econômico considerável.

Todos esses dados apontam para a necessidade de maior conhecimento no diagnóstico dos transtornos psiquiátricos. Este é o principal objetivo deste Suplemento de Psiquiatria I: revisar e ampliar o horizonte diagnóstico e o tratamento nas "Doenças" Psiquiatricas.

\section{Referências}

1. Whiteford HA, Degenhardt L, Rehm J, Baxter AJ, Ferrari AJ, Erskine HE, et al. Global burden of disease attributable to mental and substance use disorders: findings from the Global Burden of Disease Study 2010. Lancet. 2013; 382: 1575-86.

2. Juruena MF, Marques AH, Mello AF, Mello MF. A Paradigm for understanding and treating psychiatric illness. Rev Bras. Psiquiatr., 2007; 29: 1-2.

3. Juruena MF. An integrative science approach: neuroscience in the DSM-V and ICD-11. Acta Neuropsychiatr. 2011; 23: 143-4.

4. McEwen BS. From molecules to mind. Stress, individual differences, and the social environment. Ann N Y Acad Sci. 2001;935:42-9. 